\title{
Helicometrina nimia Linton, 1910 (Digenea: Opecoelidae) in dusky grouper Epinephelus marginatus (Lowe, 1834) (Teleostei: Serranidae) from southeastern Brazil
}

\author{
Roumbedakis, K. ${ }^{a}$, Marchiori, NC. ${ }^{a}$, Garcia, P. ${ }^{a}$, Pereira Junior, J. , \\ Castro, LAS. ${ }^{c}$ and Martins, ML. ${ }^{a *}$ \\ ${ }^{a}$ Aquatic Organisms Health Laboratory - AQUOS, Aquaculture Department, Federal University of Santa Catarina - UFSC, \\ Rod. Admar Gonzaga, 1346, CEP 88040-900, Florianópolis, SC, Brazil \\ bLaboratório de Biologia de Parasitos de Organismos Aquáticos, Federal University of Rio Grande do Sul - UFRGS, \\ Avenida Itália, Campus Carreiros, Prédio 6, sala 8G, Carreiros, CEP 96650-900, Rio Grande, RS, Brazil \\ 'Laboratório de Imunologia, Empresa Brasileira de Pesquisa Agropecuária - EMBRAPA-CPACT, \\ BR 392, km 78, Monte Bonito, CEP 96001-970, Pelotas, RS, Brazil \\ *e-mail: mlaterca@cca.usf.br
}

Received July 16, 2012 - Accepted March 26, 2013 - Distributed May 31, 2014

(With 4 figures)

\begin{abstract}
Helicometrina nimia (Opecoelidae) is a digenean with wide distribution. Fish families most commonly used as hosts for H. nimia are Serranidae, Pomodasydae, Scorpaenidae and Clinidae. In the present study, a new host and a new host locality are presented for the species. A description of the studied specimens, besides comments concerning its taxonomic status and biometrically compared tables of $H$. nimia reports are given. The taxonomic status of members of Helicometrina has been questionable. The greatest controversy for the genus seems to be related to the validity of diagnostic features, especially in regard to the number of testes. In the present study, all studied specimens presented a permanent and steady number of testes $(n=9)$ and therefore its use as a diagnostic character is supported by the present authors. Epinephelus marginatus is considered a new host for Helicometrina nimia, and São Paulo state, southeastern Brazil, a new locality for the species.
\end{abstract}

Keywords: parasitology, marine fish, stomach, intestine.

\section{Helicometrina nimia Linton, 1910 (Digenea: Opecoelidae) em garoupa verdadeira Epinephelus marginatus (Lowe, 1834) (Teleostei: Serranidae) no Sudeste do Brasil}

\begin{abstract}
Resumo
Helicometrina nimia (Opecoelidae) é um digenético com distribuição mundial. As famílias de peixes mais comumente utilizadas como hospedeiros por H. nimia são Serranidae, Pomodasydae, Scorpaenidae e Clinidae. No presente estudo, um novo hospedeiro e uma nova localidade são apresentados para a espécie. A descrição dos espécimes estudados, além de comentários sobre o seu status taxonômico e uma tabela comparativa de medidas de $H$. nimia são apresentados. O status taxonômico dos membros de Helicometrina tem sido questionável. A maior controvérsia dentro do gênero parece estar relacionada com a validade das características diagnósticas, especialmente no que diz respeito ao número de testículos. No presente estudo, todos os espécimes estudados apresentaram número permanente e estável de testículos $(\mathrm{n}=9)$ e, portanto, sua utilização como caráter diagnóstico é suportada pelos presentes autores. Epinephelus marginatus é considerada um novo hospedeiro para Helicometrina nimia e São Paulo, sudeste do Brasil, uma nova localidade para a espécie.
\end{abstract}

Palavras-chave: parasitologia, peixe marinho, estômago, intestino.

\section{Introduction}

Dusky grouper Epinephelus marginatus (Lowe, 1834) (Epinephelinae) is a prominent marine fish species distributed in the warmer waters of the world including the south coast of Brazil (Atlantic ocean), Mediterranean sea, Indian ocean and southern tip of South Africa (Cribb et al., 2002). It is a large fish species, growing up to lengths of 1 metre and weighing more than $40 \mathrm{~kg}$ (Smith, 1971). Epinephelines have been cultured as an important economic alternative due to losses occasioned by diseases in shrimp culture (Rückert et al., 2009). Its parasitic fauna is highlighted 
by Helicometrina species, of which half the species are found parasitising groupers (Cribb et al., 2002).

Helicometrina nimia Linton, 1910 (Digenea: Opecoelidae) is a digenean with wide distribution, noticeably wider than the other species of the genus (Oliva and Muñoz, 1985). Fish families most commonly used as hosts for $H$. nimia are Serranidae, Pomodasydae, Scorpaenidae and Clinidae (Inzunza et al., 1989).

Despite all the taxonomy controversy concerning the parasite group, the authors provide a description of the studies specimens in southeastern Brazil. Also, a new host for $H$. nimia and a comparative measurement table are presented.

\section{Material and Methods}

A total of 159 dusky grouper E. marginatus were collected from July 2009 to June 2010 in Ubatuba, SP, Brazil (2326'20'S, 45 $01^{\circ}$ '37'O). After being anesthetised with benzocaine, fish were sized, weighed, euthanized, and necropsied for the presence of parasites (Ethic Committee CEUA/UFSC-23080.029981/2009-76). The stomach and intestine were fixed separately $(10 \%$ formalin after a hot water bath of $65^{\circ} \mathrm{C}$ approximately and AFA (alcoholformalin-acetic acid), respectively) for posterior analysis by optical microscopy (OM). Digenean specimens were then washed in distilled water, stained in acetic alum carmine, diaphanised in beechwood creosote and mounted in permanent slides using Canada balsam. The ecological terms such as prevalence, mean intensity of infection and mean parasite abundance were calculated according to Bush et al. (1997). Three specimens of $H$. nimia were dissected for measurement of 22 eggs and filaments. Measurements are in millimetres, unless otherwise stated. Material was deposited in the "Helminthological Collection of Oswaldo Cruz Institute - CHIOC" under the numbers 37773 a-b.
For scanning electron microscopy (SEM) specimens were fixed in a solution of $2.5 \%$ gluteraldehyde in $0.1 \mathrm{M}$ sodium cacodylate buffer, and post-fixed in $2 \%$ osmium tetroxide. After washing several times in buffer, specimens were dehydrated in a graded series of alcohol, subjected to critical-point drying using liquid $\mathrm{CO}_{2}$ and examined using a scanning electron microscope (Zeiss DSM-940A) at EMBRAPA (Pelotas City, RS, Brazil).

For histological sections specimens of $H$. nimia previously fixed in $10 \%$ buffered formalin, were dehydrated in ascending grades of alcohol, cleared in xylene and embedded in paraffin. The sections $(3-7 \mu \mathrm{m})$ were then stained with standard Harris's haematoxylin and eosin (HH and E) stain. Permanent microscopy slides were prepared in Erv-mount.

\section{Results}

Description of Helicometrina nimia Linton, 1910

Taxonomic summary

Synonyms: Helicometrina orientalis (Srivastava, 1936) and Helicometrina elongata (Hardy, 1972) (by Deelman, 1960, not accepted by Saoud et al., 1988).

Hosts: Lutjanus griseus (Linnaeus, 1758) (=Neomaensis griseus), Lutjanus guttatus (Steindachner, 1869) (=Neomaensis guttatus), Ocyurus chrysurus (Bloch, 1791), Calamus calamus (Valenciennes, 1830), Stegastes leucostictus (Müller and Troschel, 1848) (=Eupomacentrus leucostictus), Opsanus beta (Goode and Bean, 1880), Scorpaena grandicornis Cuvier, 1829 (Type hosts, Linton, 1910); L. guttatus (=N. guttatus) (Bravo, 1954); Cephalopholis fulva (Linnaeus, 1758) (Sparks, 1957; Caballero, 1990; Nahhas and Carlson, 1994); Epinephelus analogus Gill, 1863 (Sogandares-Bernal, 1959); Scorpaena plumieri Bloch, 1789 (Siddiqi and Cable, 1960; Travassos et al., 1967); Mycteroperca rosacea (Streets, 1877) (Arai, 1962); Haemulon sciurus (Shaw, 1803),

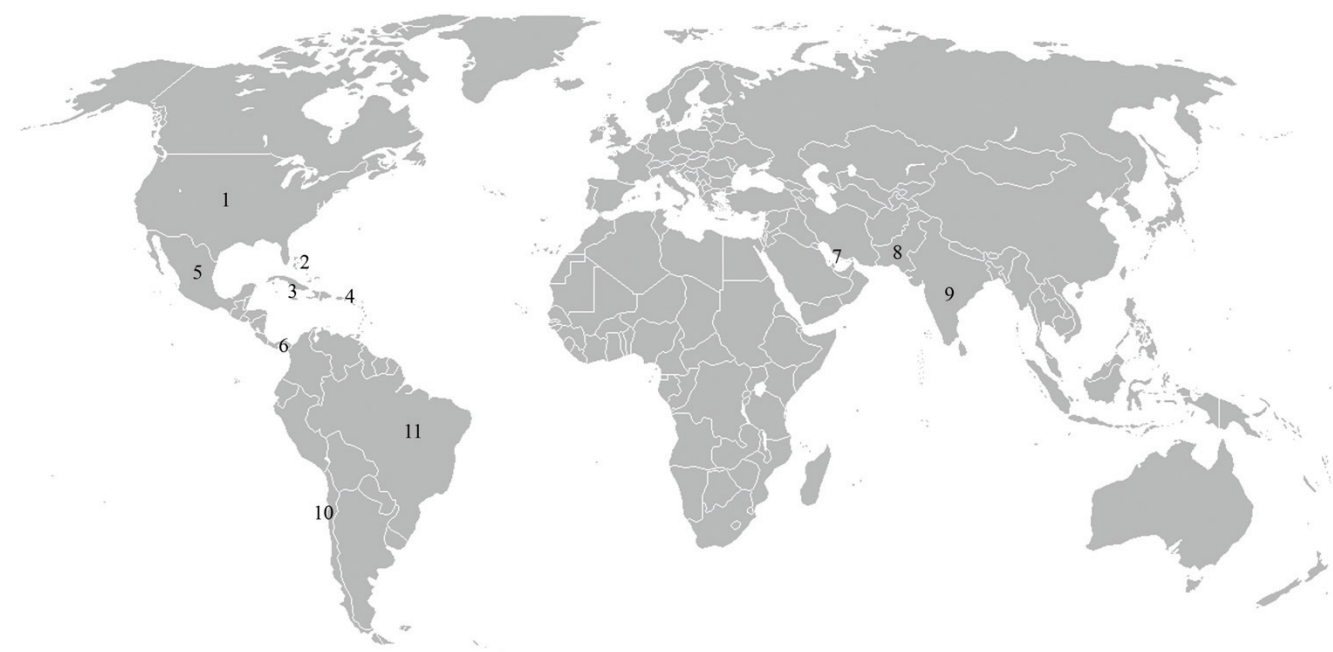

Figure 1. World distribution of Helicometrina nimia. 1. United States; 2. Bahamas; 3. Jamaica; 4. Puerto Rico; 5. Mexico; 6. Panama; 7. Arabian Gulf; 8. Pakistan; 9. India. 10. Chile; 11. Brazil. Source: adapted from http://pt.wikipedia.org/wiki/ Ficheiro:Mapa_Mundi_Detalle_Max_2008.png 
Hypoplectrus indigo (Poey, 1851), Lachnolaimus maximus (Walbaum, 1792), Lutjanus jocu (Bloch and Schneider, 1801), Bothus lunatus (=Platophrys lunatus) (Linnaeus, 1758), Sphaeroides spengleri (Bloch, 1785) (Nahhas and Cable, 1964); Lagocephalus laevigatus (Linnaeus, 1766) (Travassos et al., 1967); Epinephelus diacanthus (Valenciennes, 1828) (Zaidi and Khan, 1977; Bilqees, 1981); Nemipterus peronii $(=$ N. tolu) (Valenciennes, 1830) (Al-Yamani and Nahhas, 1981); Cymatogaster aggregata Gibbons, 1854 (Arai et al., 1988); Calliclinus geniguttatus (Valenciennes, 1836), Calliclinus nudiventris Cervigón and Pequeño, 1979 (Inzunza et al., 1989); Paralabrax humeralis (Valenciennes, 1828), Acanthistius pictus (Tschudi, 1846), Anisotremus scapularis (Tschudi, 1846) (Oliva and Muñoz, 1985); Sebastes capensis (Gmelin, 1789) (Oliva and Muñoz, 1985; Bray, 2001; Oliva and Gonzalez, 2004); Cephalopholis fulvus (Linnaeus, 1758) (Caballero, 1990); Bothus lunatus (Linnaeus, 1758) (León, 1992); Hemilutjanus macrophthalmos (Tschudi, 1846), Cheilodactylus variegatus Valenciennes, 1833, Genypterus maculatus (Tschudi, 1846) and Mugiloides chilensis (Molina, 1782) (Luque and Oliva, 1993); Lutjanus synagris (Linnaeus, 1758), Conodon nobilis (Linnaeus, 1758), Umbrina broussoneti (Cuvier, 1830) (BunkleyWilliams et al., 1996); Sebastes nebulosus Ayres, 1854 (Gibson, 1996); Epinephelus morio (Valenciennes, 1828) (Moravec et al., 1997); Polydactylus sextarius (Bloch and Schneider, 1801) (Gudivada and Vankara, 2010); Scartichthys viridis (Valenciennes, 1836) (Muñoz-Muga and Muñoz, 2010); Epinephelus marginatus (present study).

Travassos et al. (1967) reported other hosts for H. nimia such as Amphistichus argenteus Agassiz, 1854; Apogon maculatus (Poey, 1860); Apogon pseudomaculatus Longley, 1932; Balistes vetula Linnaeus, 1758; Clinocottus analis (Girard, 1858); Coryphaena hippurus Linnaeus, 1758; Embiotoca jacksoni Agassiz, 1853; Haemulon album Cuvier, 1830; Leptocottus armatus Girard, 1854; Lutjanus apodus (Walbaum, 1792); Menticirrhus undulatus (Girard, 1854); Opisthognathus maxillosus Poey, 1860; Paralabrax clathratus (Girard, 1854); Paralabrax maculatofasciatus (Steindachner, 1868); Paralabrax nebulifer (Girard, 1854); Scorpaena agassizii Goode and Bean, 1896; Scorpaena brasiliensis Cuvier, 1829; Scorpaena sonorae Jenkins and Evermann, 1889; Scorpaenichthys marmoratus (Ayres, 1854); Sebastes atrovirens (Jordan and Gilbert, 1880); Sebastodes serriceps (Jordan and Gilbert, 1880); Syacium papillosum (Linnaeus, 1758); Synodus lucioceps (Ayres, 1855); Xenistius californiensis (Steindachner, 1876).

Localities (Figure 1): Tortugas, United States (Type locality) Linton, 1910; United States (Arai et al., 1988); Bahamas (Sparks, 1957; Sogandares-Bernal and Hutton, 1959); Jamaica (Nahhas and Carlson, 1994); Puerto Rico (Siddiqi and Cable, 1960; Bunkley-Williams et al., 1996); Mexico (Manter, 1940; Bravo, 1954; Arai, 1962; Caballero, 1990; León, 1992; Moravec et al., 1997); Panama (Sogandares-Bernal and Hutton, 1959); Arabian Gulf (Al-Yamani and Nahhas, 1981); Pakistan (Bilqees, 1981); India (Gudivada and Vankara, 2010); Chile (Oliva and Muñoz, 1985; Inzunza et al., 1989; Luque and Oliva, 1993; Oliva and Gonzalez, 2004; Muñoz-Muga and Muñoz, 2010); Brazil (Travassos et al., 1967; present study).

Prevalence, mean intensity of infection, abundance and site of infection: Helicometrina nimia was observed in $19.49 \%$ of total examined fish. The mean abundance was $1.19 \pm 4.02$ and mean intensity of infection of $6.13 \pm 7.33$. In $68.42 \%$ of parasitised fish, H. nimia was found in intestine and $31.58 \%$ in stomach.

Description of the studied specimens (based in 23 specimens; 16 mature; 7 young) (Figure 2): Leaf-shaped body, $1.450 \pm 0.471(0.680-2.240)$ length and $0.444 \pm$ 0.177 (0.240-1.040) greatest width. Tegument rugose. Roughness of the tegumental surface surrounding oral and ventral sucker visible under SEM (Figures 3A-C). Oral sucker subterminal, circular, muscular, $0.135 \pm 0.037$ (0.088-0.224) length and $0.135 \pm 0.029(0.088-0.200)$ width. Pharynx muscular, $0.086 \pm 0.018(0.056-0.128)$ length and $0.083 \pm 0.019(0.040-0.128)$ width. Esophagus long, $0.091 \pm 0.042$ (0.024-0.160) length. Bifurcation of the intestinal caeca anterior to acetabulum. Caeca long,

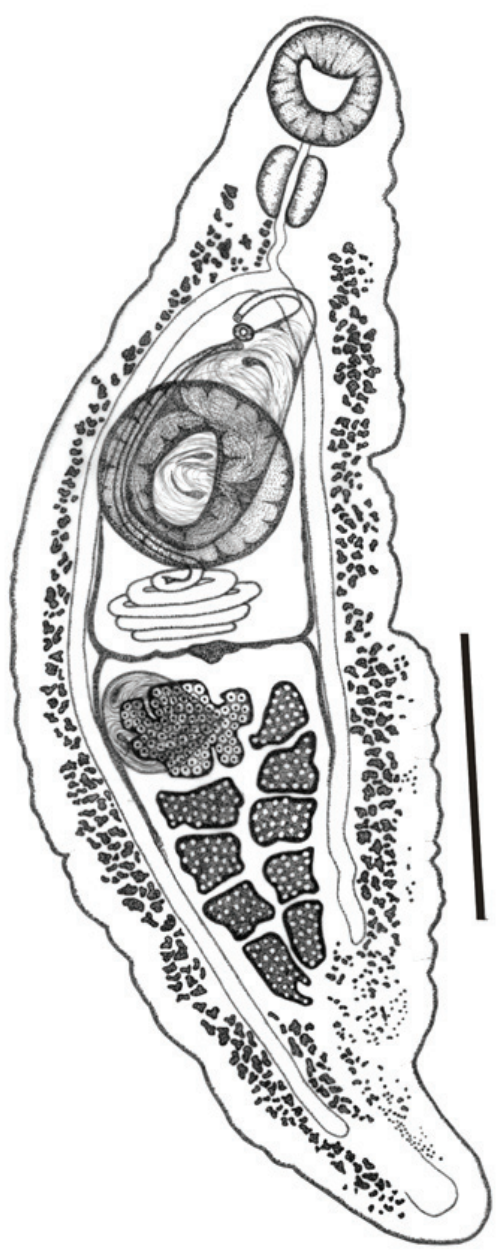

Figure 2. Helicometrina nimia Linton, 1910 from southeastern Brazil. Ventral view. Bar: $8.5 \mathrm{~mm}$. 

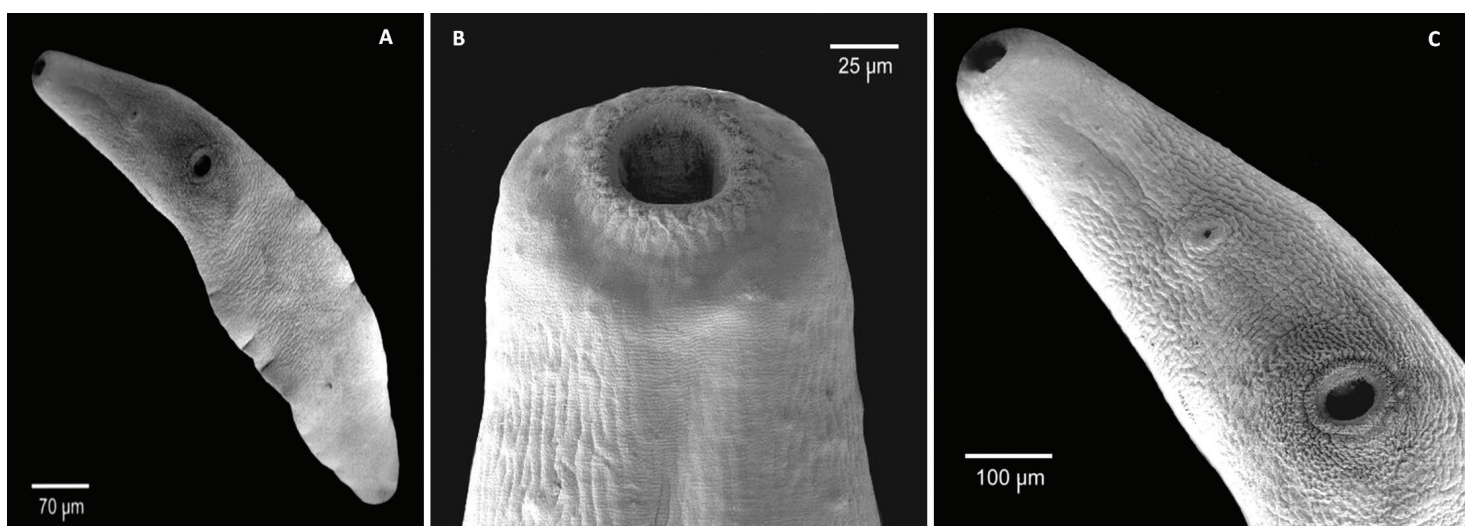

Figure 3. Scanning electron micrographs (SEM) of Helicometrina nimia. A. Whole mount (ventral view); Bar: $70 \mathrm{~mm}$. B. Anterior end showing oral sucker; Bar: $25 \mathrm{~mm}$. C. Anterior extremity showing oral sucker, genital pore and ventral sucker; Bar: $100 \mathrm{~mm}$.

A

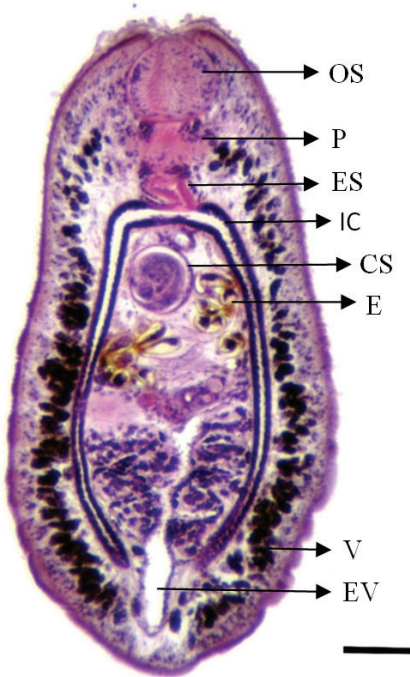

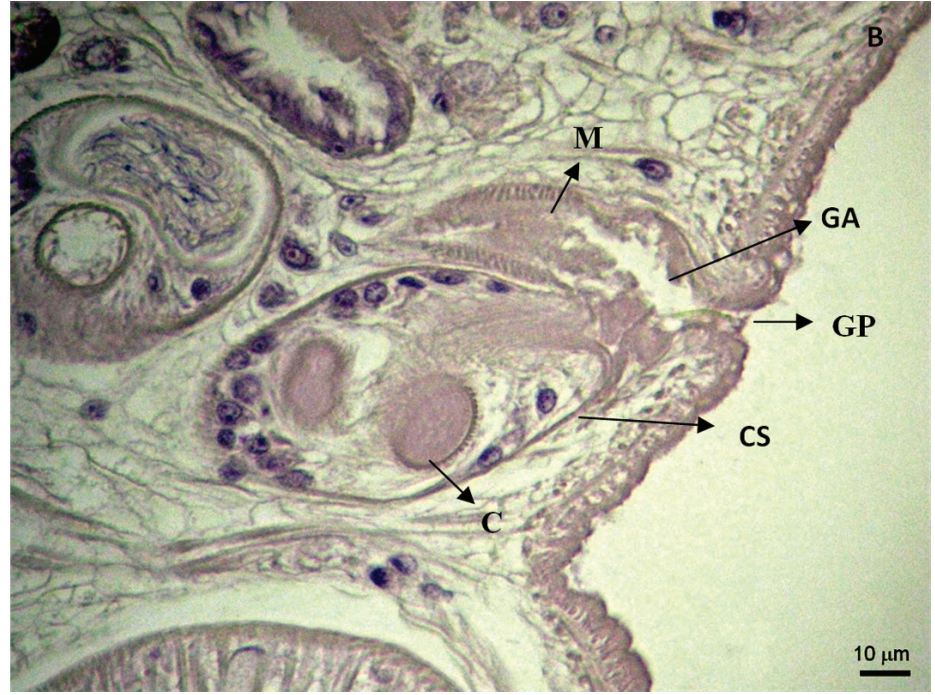

Figure 4. Histological sections of Helicometrina nimia. A. Whole mount: oral sucker (OS); pharynx (P); esophagus (ES); intestinal caecum (IC); cirrus sac (CS); egg (E); vitellaria (V); testes (T); excretory vesicle (EV). HH and E; Bar: 100 mm. B. Common genital atrium shared with metraterm and cirrus sac. Genital pore found within genital atrium. Metraterm (M); genital atrium (GA); genital pore (GP); cirrus sac (CS); cirrus (C). HH and E; Bar: $10 \mathrm{~mm}$.

terminating blindly, extending to near posterior body end. Acetabulum round, muscular, larger than oral sucker with $0.222 \pm 0.051(0.136-0.360)$ length and $0.215 \pm 0.053$ (0.136-0.296). Genital atrium anterior to acetabulum. Genital pore posterior to bifurcation, $0.466 \pm 0.074(0.376-0.544)$ away from anterior end of body. Cirrus sac large 0.159 $\pm 0.084(0.056-0.280)$ extending to posterior margin of acetabulum in mature specimens or to its equator in younger specimens. Seminal receptacle superimposed on the ovary with $0.141 \pm 0.041(0.096-0.176)$ length and 0.157 $\pm 0.036(0.120-0.192)$ width. Nine testes in two intercecal rows (four in the right row and five in the left row), with irregular shapes and $0.074 \pm 0.026(0.024-0.128)$ length and $0.089 \pm 0.032(0.024-0.168)$ width. Spiral uterus with many coils extending next to equator. Ovary with 4-6 lobes between uterus and anterior testes, with $0.126 \pm 0.044$ (0.064-0.192) length and $0.160 \pm 0.050(0.072-0.240)$ width. Vitellaria consisting of numerous irregularly shaped, densely packed follicles forming 2 extra-cecal lateral fields connected anteriorly between esophagus and cirrus sac and posteriorly in post-testicular region. Sinistral and dextral common vitelline ducts merge to form transverse median vitelline reservoir situated between uterus and ovary (Figures 4A-B). Oval egg averaging $73 \mathrm{~mm} \pm 0.008$ (60-90) long by $30 \pm 0.006 \mathrm{~mm}$ (20-40) wide with a long unipolar filament with $0.554 \pm 0.119(0.430-0.830)$ long or approximately 7.6 times length of capsule. Excretory vesicle long, median, with $0.615 \pm 0.283$ (0.216-1.056) length extending from posterior limit of ovary to posterior body extremity. Excretory pore dorso-terminal.

\section{Discussion}

Helicometrina nimia was first described by Linton (1910) from marine fishes of Tortugas, Florida and it is currently distributed in almost the entire American continent 
Roumbedakis, K. et al.

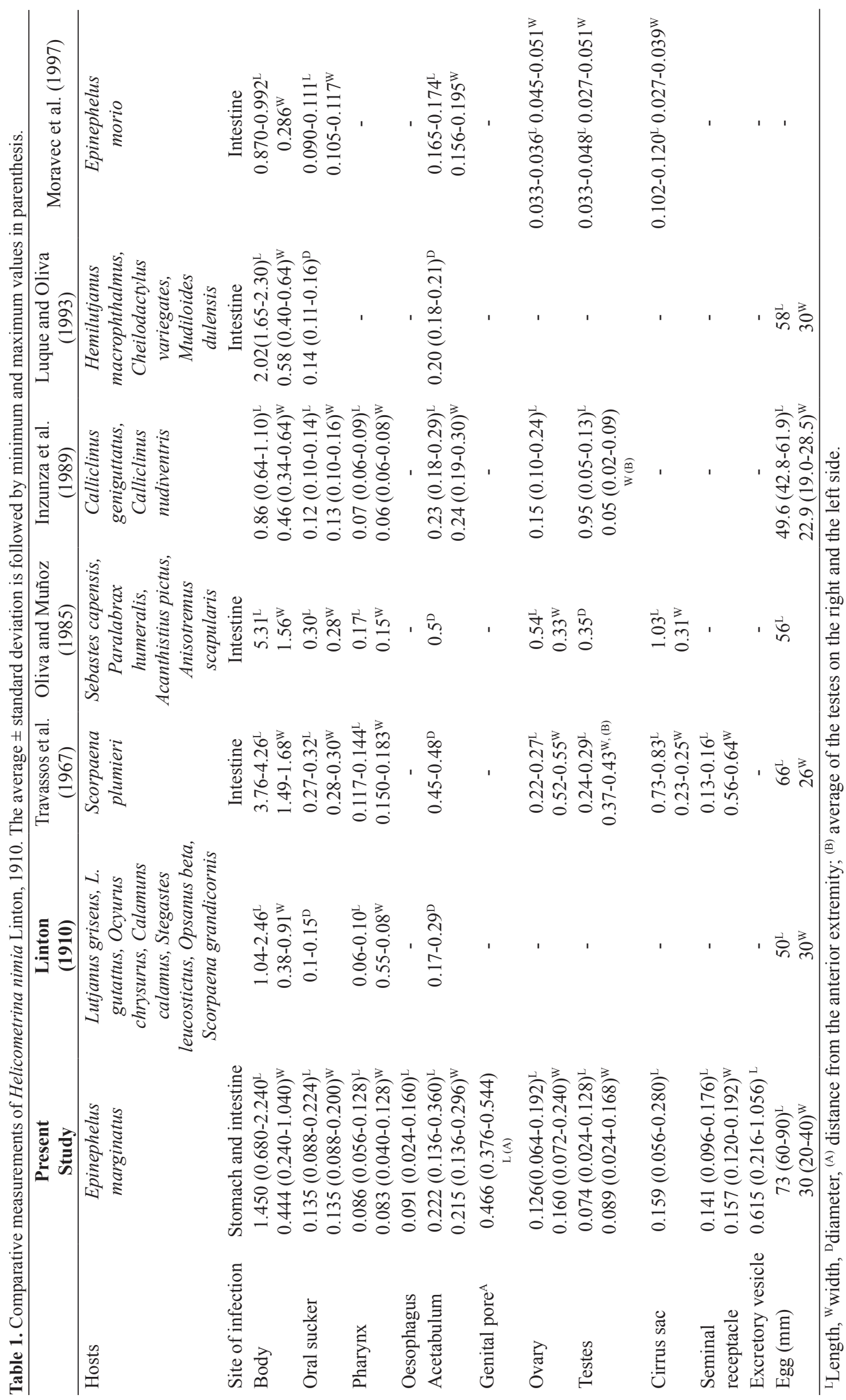


(in many fish families), besides reports from the Arabian Gulf, Pakistan and India (Al-Yamani and Nahhas, 1981; Bilqees, 1981; Gudivada and Vankara, 2010).

According to Mittal and Pande (2007), the valid species of Helicometrina are H. nimia; H. parva Manter; H. septorchis Srivastava; H. mirzai Siddiqi and Cable; H. quadrorchis Manter and Pritchard; H. hexorchis Gupta and Sehgal; H. scomberi Gupta and Jahan; H. unicum Gupta and Puri and H. chauhani Mittal and Pande. The authors also presented a key to the species of genus based on the number of testes.

Saoud et al. (1988) described H. qatarensis (not included in the valid list species proposed by Mittal and Pande (2007) and differentiated this species from $H$. nimia mainly in the position of the genital pore and the larger eggs. The authors did not recognise the synonimisation of $H$. nimia and H. orientalis proposed by Deelman (1960) since these species present a different arrangement of the vitellaria distribution, according to the former authors.

The taxonomic status of members of Helicometrina has been questionable. The greatest controversy for the genus seems to be related to the validity of diagnostic features, especially in regard to the number of testes. Hafeezullah (1971) studied 28 specimens of Helicometrina from unrelated species of marine fishes from India with varying number of testes. Except for this characteristic, the author did not report any other difference among specimens and concluded that the number of testes should not form a character to distinguish species. Later, Gibson et al. (2005) recognized the logic of the comments of the later author, but supported a distinction on the number of testes. In the present study, all studied specimens presented a permanent and steady number of testes $(n=9)$ and therefore its use as a diagnostic characteristic is supported by the present authors. Moreover, the arrangement of testes also remained the same in all analysed specimens, distributed in two rows, with four testes on the right size and five on the left. However, differently from the above studied specimens previous reports for $H$. nimia presented an inverted arrangement of the row of testicles (Oliva and Muñoz, 1985; León, 1992; Bunkley-Williams et al., 1996; Moravec et al., 1997). Even though the arrangement of testes in the present studied specimens (4 testes in the right row and 5 in the left row) was horizontally inverted when compared to previous reports for the species, the authors do not consider that this difference might support a distinct species of $H$. nimia. Linton (1910) observed that in the specimens having testes, the cells were "loosely clustered" and appeared disintegrating. Manter (1933) attributed it to the "weakness of the male gonads". Such a characteristic was not perceived in mature specimens in the present study, but it was possible to note in younger individuals the presence of testes not as compact as in the mature ones, giving the impression mentioned by both authors.

Measurements of the present studied specimens agree with previous descriptions of $H$. nimia such as those provided by Linton (1910), Inzunza et al. (1989), Luque and Oliva (1993) and Moravec et al. (1997) (Table 1).
Other features pointed out by Hafeezullah (1971) are, in fact, highly variable and should not be used for species distinction. The extent of the cirrus sac seems to be related with the parasite age. It was observed that mature specimens presented larger cirrus sac than the younger ones. It was commonly observed a fold in the anterior part of the cirrus sac (as showed in the drawings of many other previous reports), which may be responsible for a decrease in its length.

Bunkley-Williams et al. (1996) reported paddle-shaped expansions in the extremity of each caeca of $H$. nimia. Differently from the later, in the present study such a characteristic was not observed in any studied specimens.

With respect to the ovary, the authors agree with the remarks of Oliva and Muñoz (1985) since it was also observed a great variability both in shape and number of ovary's lobes, being noticed, as the only pattern, the existence of four primary lobes, which may present a varied secondary lobulation (4-6).

For all anteriorly mentioned, the authors believe that the number of testes, the position of the genital pore, the egg size, vitellaria arrangement and extension, the position and shape of the ventral sucker as well as the pharynx size are good indicators for Helicometrina species distinction. In this way, specimens analysed in the present study are considered $H$. nimia.

In the present study, Epinephelus marginatus is considered a new host for Helicometrina nimia, and São Paulo state, southeastern Brazil, can be considered a new locality for the species.

Acknowledgements - The authors thank Dr. José Luis Alejos Luque and Dr. José Luiz Pedreira Mouriño for a critical review of the manuscript prior to submission, $\mathrm{CNPq}$ - National Council of Technological and Scientific Development for the Master's scholarship for Katina Roumbedakis (CNPq 553199/2009-9) and research productivity scholarship for Dr. Maurício Laterça Martins (CNPq 302493/2010-7), the financial support for Dr. Joaber Pereira Jr. (CAPES - AUX-PE Parasitol. 1272/2011) and Instituto de Pesca, Ubatuba, SP, Brazil for their support in fish collecting. We thank the facilities of the Laboratory of Histology "Neci Moraes", Morfological Science Department, for histological sections.

\section{References}

AL-YAMANI, FY. and NAHHAS, FN., 1981. Digenetic trematodes of marine fishes from the Kuwait Coast of the Arabian Gulf. Kuwait Bulletin of Marine Science, vol. 3, p. 1-22.

ARAI, HP., 1962. Trematodos Digeneos de peces marinos de Baja California, Mexico. Anales del Instituto Ciencias del Mar y Limnologia, Universidad Nacional Autonoma de Mexico, vol. 33, p. 113-130.

ARAI, HP., KABATA, Z. and NOAKES, D., 1988. Studies on seasonal changes and latitudinal differences in the metazoan fauna of the shiner perch, Cymatogaster aggregata, along the west coast of North America. Canadian Journal of Zoology, vol. 66, n. 7, p. 1514-1517. 
BILQEES, FM., 1981. Digenetic Trematodes Fishes of Karachi Coast. Urdu Bazaar: Kifayat Academy. 207 p.

BRAVO, HM., 1954. Tremátodos de peces marinos de aguas mexicanas. VII. Anales del Instituto Ciencias del Mar y Limnologia, Universidad Nacional Autonoma de Mexico, vol. 25, p. 219-252.

BRAY, RA., 2001. Monogenea. In COSTELLO, M.J., EMBLOW, C.S. and WHITE, R. (Ed.). European register of marine species: a check-list of the marine species in Europe and a bibliography of guides to their identification. Paris: Muséum national d'histoire naturelle. p. 142-146. Collection Patrimoines Naturels, vol. 50.

BUNKLEY-WILLIAMS, L., DYER, WG. and WILLIAMS, EH Jr., 1996. Some aspidogastrid and digenean trematodes of Puerto Rican marine fishes. Journal of Aquatic Animal Health, vol. 8, no. 1, p. 87-92. http://dx.doi.org/10.1577/1548-8667(1996)008<0087:SA $\mathrm{ADTO}>2.3 . \mathrm{CO} ; 2$.

BUSH, AO., LAFFERTY, KD., LOTZ, JM. and SHOSTAK, AW., 1997. Parasitology meets ecology on its own terms: Margolis et al. revisited. The Journal of Parasitology, vol. 83, no. 4, p. 575-583. http://dx.doi.org/10.2307/3284227. PMid:9267395

CABALLERO, GR., 1990. Trematodos de peces marinos del Golfo de Mexico y del mar Caribe. II. Familias Haplosplanchnidae y Opecoelidae. Anales del Instituto de Ciencias del Mar y Limnologia Universidad Nacional Autônoma de Mexico, vol. 17, p. 191-203.

CRIBB, TH., BRAY, RA., WRIGHT, T. and PICHELIN, S., 2002. The trematodes of groupers (Serranidae: Epinephelinae): knowledge, nature and evolution. Parasitology, vol. 124, no. 07, sup. Suppl, p. S23-S42. http://dx.doi.org/10.1017/S0031182002001671. PMid:12396214

DEELMAN, JJ., 1960. Studies on the genus Helicometrina Linton, 1910 (Trematoda: Digenea: Allocreadiidae). The Journal of Parasitology, vol. 46, no. 5, p. 2-13

GIBSON, DI., 1996. Trematoda. In MARGOLIS, L. and KABATA, Z. (Ed.). Guide to the parasites of fishes of Canada. Part IV. Trematoda. 373 p. Ottawa National Research Council of Canada. Canadian Special Publications of Fisheries and Aquatic Sciences, vol. 124.

GIBSON, DI., JONES, A. and BRAY, RA., 2005. Keys to the Trematoda. Wallingford: CAB International. 745 p. vol. 2.

GUDIVADA, M. and VANKARA, AP., 2010. Population dynamics of metazoan parasites of marine threadfin fish, Polydactylus sextarius (Bloch and Schneider, 1801) from Visakhapatnam coast, Bay of Bengal. The Biascan, vol. 5, no. 4, p. 555-561.

HAFEEZULLAH, M., 1971. A review on the validity of Helicometrina Linton, 1910 and Stenopera Manter, 1933 (Trematoda). Acta Parasitologica Polonica, vol. 19, p. 133-139.

INZUNZA, A., TORRES, P. and FRANJOLA, R., 1989. Nuevos hospedadores para Helicometrina nimia Linton, 1910 (Digenea: Opecoelidae) en la costa centro sur de Chile. Boletin Chileno de Parasitologia, vol. 44, no. 1-2, p. 41-43. PMid:2629771.

LEÓN, GPP., 1992. Helicometrina nimia parásito de Bothus lunatus de Puerto Morelos, Quintana Roo, México. Anales del Instituto de Biología. Serie Zoología, vol. 63, no. 1, p. 147-150.

LINTON, E., 1910. Helminth fauna of the Dry Tortugas II. Trematodes. Papers from the Tortugas Laboratory of the Carnegie Institute of Washington, vol. 4, p. 11-98.

LUQUE, J. and OLIVA, M., 1993. Trematodes of marine fishes from the Peruvian Faunistic Province (Peru and Chile), with description of Lecithochirium callaoensis n.sp. and new records. Revista de Biologia Marina, vol. 28, no. 2, p. 271-286.

MANTER, HW., 1933. The genus Helicometra and related trematodes from Tortugas, Florida. Papers from Tortugas Laboratory of the Carnegie Institute of Washington, vol. 28, no. 11, p. 167-182.

MANTER, HW., 1940. Digenetic trematodes of fishes from Galápagos Islands and neighboring Pacific. Allan Hancock Pacific Expedition, vol. 2, no. 14, p. 329-497.

MITTAL, N. and PANDE, PN., 2007. On a new Trematode of the genus Helicometrina Linton, 1910 from the intestine of a marine fish, Chrysophrys sarba (Cuv and Vol) from puri coast, Orissa. In PANDEY, BN. and KULKARNI, GK. (Ed.). Environment and Development. New Delhi: A.P.H. Publishing Corporation. p. 145-152. vol. 1

MORAVEC, F., VIDAL-MARTÍNEZ, VM., VARGAS-VÁZQUEZ, J., VIVAS-RODRÍGUEZ, C., GONZÁLEZ-SOLÍS, D., MENDOZAFRANCO, E., SIMÁ-ALVAREZ, R. and GÜEMEZ-RICALDE, J., 1997. Helminth parasites of Epinephelus morio (Pisces: Serranidae) of the Yucatan Peninsula, southeastern Mexico. Folia Parasitologica, vol. 44, no. 4, p. 255-266. PMid:9437838.

MUÑOZ-MUGA, P. and MUÑOZ, G., 2010. Parasite communities of Scartichthys viridis (Pisces: Blenniidae) from Central Chile: locality vs. Host length. Revista de Biologia Marina y Oceanografia, vol. 45 , no. 1 , p. 165-169.

NAHHAS, MF. and CABLE, RM., 1964. Digenetic and Aspidogastrid Trematodes from marine fishes of Curaçao and Jamaica. Tulane Studies in Zoology and Botany, vol. 11, no. 5, p. 167-228.

NAHHAS, FM. and CARLSON, K., 1994. Digenetic trematodes of marine fishes of Jamaica, West Indies. Publications of the Hofstra University Marine Laboratory. Ecological Survey of Jamaica, vol. 2, p. 1-60.

OLIVA, ME. and GONZALEZ, MT., 2004. Metazoan parasites of Sebastes capensis from two localities in northern Chile as tools for stock identification. Journal of Fish Biology, vol. 64, no. 1, p. 170-175. http://dx.doi.org/10.1111/j.1095-8649.2004.00295.x.

OLIVA, ME. and MUÑOZ, MA., 1985. Helicometra fasciata (Rudolphi, 1819) y Helicometrina nimia Linton, 1910 (Trematoda: Opecoelidae) en peces marinos de la II Región, Chile. Parasitología al Día, vol. 9, p. 107-111.

RÜCKERT, S., KLIMPEL, S., AL-QURAISHY, S., MEHLHORN, H. and PALM, HW., 2009. Transmission of fish parasites into grouper mariculture (Serranidae: Epinephelus coioides (Hamilton, 1822)) in Lampung Bay, Indonesia. Parasitology Research, vol. 104 , no. 3, p. 523-532. http://dx.doi.org/10.1007/s00436-0081226-7. PMid: 18855012

SAOUD, MFA., RAMADAN, MM. and AL-KAWARI, KSR., 1988. Helminth parasites of fishes from the Arabian Gulf. 4. On Allacanthochasmus lutjani n. sp. and Metadena leilae Nagaty, 1957 (Digenea: Cryptogonimidae). Qatar University Science Bulletin, vol. 8, p. 161-172

SIDDIQI, A. and CABLE, R., 1960. Digenetic trematodes of marine fishes of Puerto Rico. Scientific Survey of Porto Rico and Virgin Islands, vol. 17, no. 3, p. 260-325.

SMITH, CL., 1971. A revision of the American groupers: Epinephelus and allied genera. Bulletin of the American Museum of Natural History, vol. 146, p. 1-242. 
SOGANDARES-BERNAL, F., 1959. Digenetic trematodes of marine fishes from the Gulf of Panama and Bimini, British West Indies. Tulane Studies in Zoology, vol. 7, no. 3, p. 71-117.

SOGANDARES-BERNAL, F. and HUTTON, RF., 1959. Studies on helminth parasites from the coast of Florida. III. Digenetic trematodes of marine fishes from Tampa and Boca Ciega Bays. The Journal of Parasitology, vol. 45, no. 3, p. 337-346. http:// dx.doi.org/10.2307/3274511. PMid:13665474
SPARKS, AK., 1957. Some digenetic trematodes of marine fishes of the Bahama Islands. Bulletin of Marine Science of the Gulf and Caribbean, vol. 7, no. 3, p. 255-265.

TRAVASSOS, L., FREITAS, JFT. and BÜHRNHEIM, PF., 1967. Relatório da excursão do Instituto Oswaldo Cruz ao estado do Espírito Santo em novembro de 1964. Boletim do Museu de Biologia Prof. Mello Leitão. Zoologia, vol. 31, p. 1-5.

ZAIDI, DA. and KHAN, D., 1977. Digenetic trematodes of fishes from Pakistan. Bulletin of the Department of Zoology University of the Panjab, vol. 9, p. 1-56. 